\title{
Relationships between soil quality indicators, redox properties, and bioactivity of humic substances of soils under integrated farming, livestock, and forestry
}

\author{
Marihus Altoé Baldotto ${ }^{1}$, Lílian Estrela Borges Baldotto ${ }^{1}$
}

10.1590/0034-737X201865040010

\begin{abstract}
Once it is stabilized in the soil, organic matter minimizes limitations of Brazilian Oxisols, such as low cation exchange capacity, low nutrient availability, toxicity due to high aluminum content, and phosphate adsorption. Moreover, humified organic matter fractions are bioactive. It is, therefore, important to evaluate the biostimulant ability of compounds present in soil carbon stocks to develop sustainable technologies for tropical agriculture based on renewable natural resources. The objective of this research was to correlate some soil quality indicators, redox properties, and bioactivity of humic acids isolated from integrated farming, livestock, and forestry systems aiming to understand the mechanisms involved in plant stimulation by humified organic matter. Carbon stocks and their stability were determined from oxidation by dichromatometry and iodometry, respectively. Bioactivity was assessed using yield data of corn indicator plants. The results indicated that when native-like forests were reintroduced instead of pastureland, soil carbon stocks and their stability increased along with overall improvements in soil fertility, chemical and physical properties, and soil biodiversity. The bioactivity of humic substances isolated from soils used in integrated crop, livestock, and forestry management was higher than that of soils derived from pastures or eucalyptus alone.
\end{abstract}

Keywords: organic matter; humic acids; agrosilvopastoral systems.

\section{RESUMO}

\section{Relações entre indicadores de qualidade do solo, propriedades redox e bioatividade de substâncias húmicas de solos sob integração lavoura, pecuária e florestas}

Uma vez estabilizada no solo, a matéria orgânica minimiza limitações intrínsecas dos Latossolos brasileiros, tais como, as baixas capacidade de troca de cátions e disponibilidade de nutrientes e elevadas toxidez por alumínio e adsorção de fosfatos. Adicionalmente, frações humificadas da matéria orgânica apresentam bioatividade, sendo, portanto, importante a avaliação da capacidade bioestimulante de compostos presentes nos estoques de carbono do solo, visando desenvolver tecnologias com bases em recursos naturais renováveis para a agropecuária tropical, com preservação ambiental. O presente trabalho objetivou correlacionar alguns indicadores de qualidade do solo, propriedades redox e bioatividade dos ácidos húmicos isolados de sistemas de integração lavoura, pecuária e florestas, visando compreender mecanismos da estimulação de plantas pela matéria orgânica humificada. Os estoques de carbono e as suas estabilidades foram determinados a partir da oxidação por dicromatometria e por iodimetria, respectivamente. A bioatividade foi obtida pelo desempenho inicial de plantas indicadoras de milho. Os resultados indicaram que houve aumento dos estoques de carbono no solo e nas suas estabilidades, além de melhorias gerais na fertilidade do solo, nos aspectos químicos, físicos e biológicos, com a reintrodução das florestas, em relação às pastagens, tendendo a assemelhar-se às matas nativas. A bioatividade das substâncias húmicas isoladas de solos manejados com integração lavoura, pecuária e florestas foi também superior a uso de apenas pastagens ou eucalipto isoladamente.

Palavras-chave: matéria orgânica; ácidos húmicos; sistemas agrossilvipastoris.

\footnotetext{
Submitted on April 04th, 2018 and accepted on August 27th, 2018.

' Universidade Federal de Viçosa, Instituto de Ciências Agrárias, Florestal, Minas Gerais, Brasil. marihus@ufv.br; lilian.estrela@ufv.br

*Corresponding author: marihus@ufv.br
} 


\section{INTRODUCTION}

Soil organic matter preservation is the first step in the process of agroecosystem recovery. Conservationist agricultural practices are required thereafter to increase soil carbon stocks and their stability, so that they can be retained in the system (sequestration) (Baldotto et al., 2010). The preservation of the organic matter in soil helps to ensure a high soil quality (Cerri et al., 2003; Carvalho et al., 2010; Baldotto et al., 2015; IHSS, 2016).

The Brazilian Ministry of Agriculture (MAPA, 2016) committed to reducing greenhouse gas emissions by recovering 15 million hectares of degraded pastures between 2010 and 2020. The pastureland soil declined in productivity due to biological, chemical, and physical deterioration and could no longer retain carbon. This environmental degradation exacts a high cost to society and destroys the livelihood of farmers.

According to MAPA (2016), about 30 million hectares of pasture in Brazil are in some stage of degradation and produce very little animal feed. The correct use of agrotechnology and good agricultural practice (GAP) helps to improve farmland productivity. Some of these technologies include organic agriculture, integrated production systems, integrated farming-livestock-forest (IFLF) management, direct planting, and agroforestry systems. All of these have high potential to improve soil fertility (Baldotto et al., 2015).

Soil fertility is renewed via chemical (charge generation, nutrient availability, toxic ion and pollutant complexation, reduction in phosphate adsorption, etc.), physical (aggregation, improvement of porosity, air flow, and soil solution mobility, reductions in density, compression and penetration resistance, etc.), and biological (increase in the numbers of organisms, biodiversity, symbionts, and bioactive substances which stimulate plant growth, etc). All these improvements are necessary for tropical Latosols (Baldotto et al., 2010). Especially troublesome in these soils are the lack of negative electrical charges (low cation exchange capacity - CEC), high phosphate fixation, low nutrient availability, and high aluminum $\left(\mathrm{Al}^{3+}\right)$ concentrations. These problems can all be minimized by increasing and conserving soil organic carbon content since its electrically charged functional groups raise CEC, prevents phosphate adsorption, and recycle nutrients and complex aluminum ions (Baldotto et al., 2010).

Latosols are distributed throughout Brazil and are most representative of Brazilian soils (Embrapa, 2018). They constitute about $60 \%$ of the country's soil and have great potential for agriculture. Preserving carbon stocks could be an efficient way to enhance the useful properties of Latosols. The integration of farming, livestock, and forestry systems (agroforestry) enables organic matter recovery (Baldotto et al., 2015).
The integration of farming, livestock, and forestry consists in the implementation of grain, wood, meat, milk, and agroenergy production systems in rotation. It recovers or reforms pastureland, improves physical and biological soil characteristics, reduces costs, and diversifies and stabilizes farmer income (Viana et al., 2010; Vilela et al., 2011; Coelho et al., 2014).

Monocultures based on non-renewable natural resources must be phased out in this new millennium. They cause loss of biodiversity and soil degradation. In some cases, conventional agrosystems have a negative carbon balance (Baldotto et al., 2010). Atmospheric emissions of previously soil-sequestered carbon may aggravate the greenhouse effect (IPCC, 2016)

In crop, livestock, and forest integration systems, plant residue influx differs from that of conventional production systems, both on the soil surface and in the soil profile. Organic matter accumulates on the soil surface in the form of soil cover and, in deeper layers, through root growth. In diversified ecosystems, nutrient cycling is more efficient than in monoculture systems (Araújo et al., 2007; Macedo, 2009; Viana et al., 2010).

Soil carbon stocks are thought to increase with crop, livestock, and forest integration (Baldotto et al., 2015) and improve chemical, physical, and biological fertility. The increase in carbon stocks is accompanied by the stabilization (sequestration) of persistent humic substances. This property improves Latosol quality and raises its bioactivity, resulting in better plant performance (Canellas et al., 2008; Baldotto et al., 2017).

The bioactivity of humic substances is attributed to auxin residues retained in sites in the supramolecular arrangements (Piccolo, 2001) as reviewed by Baldotto \& Baldotto (2014). Bioactivity, therefore, requires a bioprovenance property, which is the ability to preserve biopolymers during the humification process (Sposito, 2008). Thus, it is hypothesized that redox sites may contribute to bioprovenance in humic substances and thus increase the retention of auxin residues responsible for the mechanism of plant stimulation.

The objective of this research was correlate some soil quality indicators, redox properties, and bioactivity of humic acids isolated from integrated farming, livestock, and forestry systems aiming to understand the mechanisms involved in plant stimulation by humified organic matter.

\section{MATERIAL AND METHODS}

The study was conducted in the Universidade Federal de Viçosa - Campus Florestal (UFV-CAF) located at $19^{\circ} 52^{\prime} 16.3^{\prime \prime} \mathrm{S}$ and $44^{\circ} 25^{\prime} 26.1$ ' $\mathrm{W}$ at an altitude of approximately $750 \mathrm{~m}$. The area is in the federal basin of the 
São Francisco River and in the regional basin of the Paraopeba River, within the range of two sub-basins, Ribeirão das Lages and Ribeirão do Ouro (CBHSF, 2016; Cibapar, 2016).

\section{Soil quality indicators}

The sampled soil is a Dystrophic Yellow Argisolic Latosol, according to the Brazilian System of Soil Classification (Embrapa, 2018).

Composite soil samples were collected from the 0-20 $\mathrm{cm}$ layer. The soil samples were crushed, sieved in 2-mm meshes, and dried in the shade on a bench to prepare airdried fine soil (TFSA) to be used in chemical and physical soil analyses (Embrapa, 1997). The soil characterization was performed previously by Baldotto et al. (2015).

The carbon stocks (CS) were determined using the organic carbon and soil density values as follows:

$C S=C x p \times S D \times 10$

in which $\mathrm{C}$ is the organic carbon content in $\mathrm{g} \mathrm{kg}^{-1}, \mathrm{p}$ is the depth of the layer sampled in $\mathrm{m}$, and SD is the soil density in $\mathrm{kg} \mathrm{m}^{-3}$ (Baldotto et al., 2010).

The fractionation, extraction, and purification of soil organic carbon were performed by Baldotto et al. (2015) according to the methods recommended by the International Humic Substances Society (IHSS, 2016).

\section{Redox properties of humic substances}

Redox titrations were performed by oxidizing humic substances with $\mathrm{I}_{2}$ (iodometry), under an inert atmosphere and other specified conditions (Struyk \& Sposito, 2001; Baldotto et al., 2010).

\section{Bioactivity of humic substances}

The experiment was conducted in the campus of the Universidade Federal de Viçosa, by Baldotto et al. (2017) during the second half of 2014, in partnership with the Central West regional unit of the Empresa de Pesquisa Agropecuária de Minas Gerais.

Humic substances isolated from integrated farming, livestock, and forestry systems were applied to the seeds of an indicator plant, AG1051 corn (Zea mays). Plant performance was evaluated in terms of root and aerial shoot biomass production. The humic substances extracted from soils under integrated farming, livestock, and forestry systems ("Integration") were compared with those from soils under eucalyptus plantations ("Eucalyptus"), pasture ("Pasture"), and cerrado ("Forest").

The maize seeds were subjected for $4 \mathrm{~h}$ to the humic substances isolated from each soil type (forest, eucalyptus, pasture, and integration). The predetermined carbon concentration was $20 \mathrm{mmol} \mathrm{L}^{-1}$. Humic substances were extracted according to the methodology prescribed by the International Humic Substance Society described in Baldotto \& Baldotto (2014).

The control seeds were soaked in distilled water so that they would absorb quantities of water similar to those for the treated seeds.

The experimental units consisted of $1 \mathrm{dm}^{3}$ pots filled with soil from the 20-40 cm layer of a typical Dystrophic Red Latosol. The soil was limed and fertilized according to the method described in Ribeiro et al. (1999). The amended, fertilized soils were transferred to the plastic pots and five corn seeds were planted in each one. After germination, three seedlings were removed from each pot.

The experimental design was completely randomized with five replications, for a total of 25 experimental units. They were monitored daily throughout the experiment and irrigated to maintain the field capacity between $80-100 \%$. Other variables, such as weed and pest control and illumination, were maintained for all treatments.

At the end of the bioassay, 45 days after planting (DAP), plants were cut flush with the soil surface and weighed on a precision balance. The roots were extracted, carefully desoiled, washed, and weighed. Both the shoots and roots were packed in paper bags and dried to a constant weight in a forced-ventilation oven at $60{ }^{\circ} \mathrm{C}$ for $72 \mathrm{~h}$. Total fresh and dry biomasses were determined using the fresh and dry root and shoot weights.

\section{Statistical analysis}

Standard deviations of the means (Steel \& Torrie, 1980) were estimated between for the soil quality indicators. Bioactivity data were subjected to analysis of variance (ANOVA). Qualitative factors (origin of HA) were compared with a contrast of means using the same test and significance levels as above, and the quantitative factors (concentrations of HA) were compared by regression analysis (Alvarez V \& Alvarez, 2003). Models were tested when their coefficient of determination exceeded 0.60 . F tests were performed at 10,5 , and $1 \%$ probability. Soil quality indicators, redox properties, and bioactivity of humic acids were correlated (Steel \& Torrie, 1980) using the Genes program (Cruz, 2006).

\section{RESULTS AND DISCUSSION}

Tables 1, 2 and 3 shows the soil carbon stocks, estimates of their stability (redox index), and the biostimulant capacity of the humic substances.

Carbon stocks were higher in soils under forests than those under pastureland. Data for CS and estimates of their stability (as determined by the HA/FA ratio, which is proportional to the persistence of the material in the soil) were discussed in Baldotto et al. (2015) and, in the present 


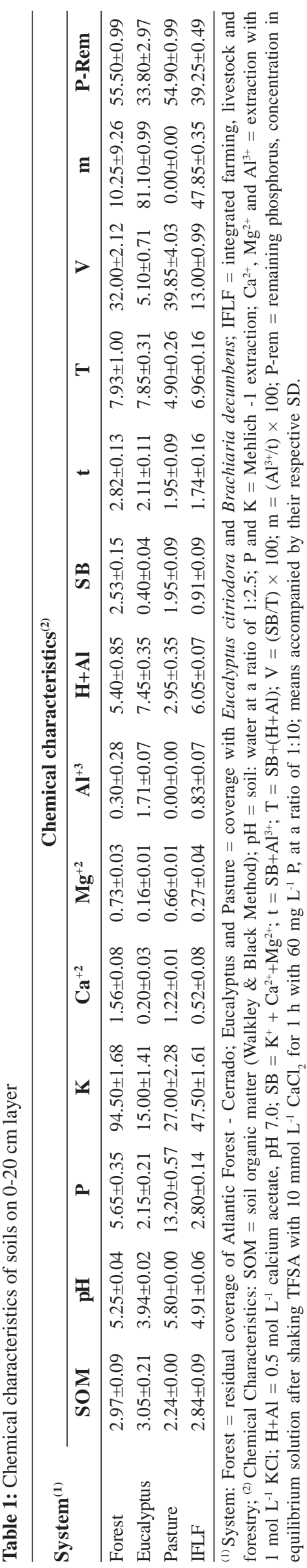

study, were used to build the correlation database. Considering the margin of error, HA/FA stabilities did not significantly differ among treatments.

In contrast, the redox index of carbon stability (RICS) (Baldotto et al., 2010) differed significantly among the samples. The redox index of carbon stability in the forest area and IFLF were the highest, followed by that for the eucalyptus stand. By comparison, pastures had relatively lower carbon stocks and less persistent sequestered carbon.

The bioactivity of humic substances isolated from forest soils indicated that the forests contributed to improvements in soil quality. Pastureland soils had the lowest bioactivity, whereas those sampled from the integration of farming, livestock, and forests had the highest bioactivity. These data were discussed by Baldotto et al. (2017) and are included in this report.

\section{Correlations}

Correlation matrices were prepared to determine the degree of association between the aforementioned variables and other fundamental soil attributes analyzed in this present study (Tables 1, 2, and 3).

Tables 4, 5, and 6 show the correlation coefficients between carbon stocks, their stability, bioactivity of organic matter, and soil fertility. In general, increases in soil carbon content and soil fertility are closely correlated.

Some soil nutrient levels apparently decreased, possibly because they were immobilized or formed nonextractable complexes with mineral colloids.

Soil potassium levels increased with CS stability, which indicates that, unlike certain other nutrients, its availability does not depend on high rates of organic detritus conversion, and it is cycled in the soil system. Nevertheless, extraction and analytical methods are required to estimate its availability in agroforestry systems.

Buffering capacity (estimated from $\mathrm{H}+\mathrm{Al}$ ) increases with soil carbon sequestration. Since it contains functional carboxylic acid groups and phenolic compounds, organic matter usually increases soil acidity and resists changes in $\mathrm{pH}$ and other physicochemical properties.

Ion exchange is associated with both the increase and stability of soil carbon stocks because it generates charges. At $\mathrm{pH} 7$, total CEC increased, improving nutrient retention capacity, increasing resistance to perturbations from pollutants, and minimizing the risk of leaching. A limitation of Brazilian Latosols is low CEC.

Soil conservation protects and enhances soil organic matter and has other benefits as well. Increasing CS generates the electrical charge necessary for soil nutrient retention. Thus, it retards mineral leaching, promotes plant nutrient availability, and helps fertilize weathered tropical soils. 
The total cation exchange capacity increased with soil carbon sequestration $\left(\mathrm{R}^{2}=0.8524\right)$ as follows:

$$
\text { CEC at } \mathrm{pH} 7=-1.8290=0.2618 \mathrm{CS}
$$

indicating that for each increment of tonne per hectare $(=$ $\mathrm{Mg} / \mathrm{ha}$ ) in the carbon stock, the value of CEC at $\mathrm{pH} 7$ increased by $0.2618 \mathrm{cmol} / \mathrm{dm}^{3}$.

These data align with electrical charge increase, which is incorporated in the RICS estimates. A high organic matter reducing power is a source of electrons for soil reactions and improves both geochemistry and nutrient cycling.

These improvements are reflected in the fact that the bioactivity of humic substances in soil carbon stocks is stronger in conservation than in conventional systems.

The bioactivity represents the growth stimulating or regulating capacity of humic substances (Baldotto et al., 2014) and is attributable to the presence of residual phytohormones released during the humification process.

The relationship between the bioactivity of humic substances and RICS $\left(\mathrm{R}^{2}=0.7031\right)$ is expressed by the following equation:

\section{Bioactivity $=-112.6800+2.1096$ RICS}

After maize seeds have been treated with humic substances, their bioactivity increases $2.1096 \%$ over the control for every $1 \mathrm{kmol} / \mathrm{ha}$ increase in RICS.

Humic substances are bioactive in part because they contain hormone residues in their structure. The hydropho- bic and aromatic nature of stable carbon in combination with the hydrophilic and aliphatic character of humic substances results in a supramolecular structure with a large ion retention capacity (Sposito, 2008; Piccolo, 2001). They also hold plant growth regulators (Taiz \& Zeiger, 2003) which are not degraded during organic debris humification. The redox index of carbon stability is a sensitive index of structural/conformational changes in humus. It increases in proportion to the accumulation of stimulant biopolymers such as auxin residues, which are not decomposed by microorganisms as are other polymers like sugars, carbohydrates, proteins, cellulose, lignin, etc., whose breakdown products remain within the humic supramolecular structure. The solubilization of organic matter enables it to be reused by plants, and the isolation of humic substances makes them bioactive and biostimulant in plants (Canellas et al., 2002; Nardi et al., 2002; Baldotto et al., 2011; Canellas \& Olivares, 2014; Baldotto et al., 2014).

Since the duration of the experiment was relatively short ( $<8$ years), it was not possible to infer carbon cycle mechanisms or processes from the physical attributes assessed. These variables might require a longer evaluation period (Anjos et al., 1994) to demonstrate the relationships between them. Nevertheless, there tends to be an inverse relationship among particle density, RICS, and bioactivity. Organic matter has a relatively low particle density, so it may decrease RICS, which also declines with the increase in total porosity. Pore size enlargement may have been

Table 2: Particle density, soil density, total calculated porosity, and mean resistance to soil penetration

\begin{tabular}{|c|c|c|c|c|}
\hline \multirow{2}{*}{ System $^{(1)}$} & $\mathbf{P D}^{(2)}$ & $\mathbf{S D}^{(3)}$ & \multirow{2}{*}{$\begin{array}{c}\mathbf{T P}^{(4)} \\
\%\end{array}$} & \multirow{2}{*}{$\begin{array}{c}\text { MSRP }^{(5)} \\
k P a\end{array}$} \\
\hline & \multicolumn{2}{|c|}{$\mathrm{g} / \mathrm{cm}^{-3}$} & & \\
\hline Forest & $2.58 \pm 0.02$ & $1.00 \pm 0.02$ & 61.24 & $1,981 \pm 108$ \\
\hline Eucalyptus & $2.61 \pm 0.03$ & $1.07 \pm 0.01$ & 59.00 & $1,889 \pm 138$ \\
\hline Pasture & $2.62 \pm 0.03$ & $1.01 \pm 0.03$ & 59.16 & $2,145 \pm 173$ \\
\hline Integration & $2.60 \pm 0.02$ & $1.07 \pm 0.01$ & 61.50 & $1,440 \pm 68$ \\
\hline
\end{tabular}

(1) System: Forest $=$ residual coverage of Atlantic Forest-Cerrado; Eucalyptus and Pasture $=$ coverage with Eucalyptus citriodora and Brachiaria decumbens; IFLF = integrated farming, livestock, and forestry; ${ }^{(2)} \mathrm{PD}=$ particle density; ${ }^{(3)} \mathrm{SD}=$ soil density; ${ }^{(4)} \mathrm{TP}=$ total porosity; ${ }^{(5)}$ MSRP = mean resistance to soil penetration.

Table 3: Carbon stocks, RICS, and bioactivity of humic substances isolated from integrated farming, livestock, and forest systems, and adjacent control areas

\begin{tabular}{|c|c|c|c|c|}
\hline System $^{(1)}$ & $\mathrm{CS}(\mathrm{Mg} / \mathrm{ha})^{(2)}$ & $\mathbf{H A} / \mathbf{F A} \mathbf{A}^{(3)}$ & $\operatorname{RICS}(\mathbf{k m o l} / \mathbf{h a a})^{(4)}$ & Bioactivity (g/plant) ${ }^{(5)}$ \\
\hline & \multicolumn{4}{|c|}{ Control $\mathrm{H}_{2} \mathrm{O}=0.6850 \pm 0.01(100 \%)$} \\
\hline Forest & $34.24 \pm 1.79$ & $1.23 \pm 0.12$ & $103.06 \pm 2.00$ & $1.2369 \pm 0.02(181 \%)$ \\
\hline Eucalyptus & $37.81 \pm 3.04$ & $1.15 \pm 0.20$ & $91.12 \pm 1.55$ & $1.2293 \pm 0.02(179 \%)$ \\
\hline Pasture & $26.25 \pm 0.73$ & $1.12 \pm 0.11$ & $75.60 \pm 1.04$ & $1.0214 \pm 0.01(149 \%)$ \\
\hline IFLF & $35.18 \pm 0.68$ & $1.11 \pm 0.04$ & $105.89 \pm 2.01$ & $1.5938 \pm 0.02(233 \%)$ \\
\hline
\end{tabular}

(1) System: Forest $=$ area of adjacent cerrado; Eucalyptus = conventional eucalyptus stand; Pasture = conventional pasture consisting of Brachiaria; IFLF = integrated farming, livestock, and forestry; ${ }^{2)} \mathrm{CS}=$ soil organic carbon stock; ${ }^{(3)} \mathrm{HA} / \mathrm{FA}=$ ratio of humic acids fractions to fulvic acid fractions; ${ }^{(4)}$ RICS $=$ redox index of carbon stability; ${ }^{(5)}$ Bioactivity estimated from total root and shoot fresh weights of maize (indicator) plants derived from maize seeds that had been subjected to $20 \mathrm{mmol} \mathrm{L}^{-1}$ carbon for $4 \mathrm{~h}$. 
Table 4: Matrix of correlations of carbon stocks, their stabilities, and their bioactivities with selected soil fertility attributes (correlation was considered narrow when $r>0.7000$ )

C $0.9679-0.8$

$\begin{array}{cc}\mathbf{p H} & \mathbf{P} \\ -0.8862 & -0.9833\end{array}$

$\mathbf{K} \quad \mathbf{C a}^{2+}$

$\mathbf{M g}^{2+}$

$\mathbf{A l}^{3+}$

$\mathbf{H}+\mathbf{A l}$

$\begin{array}{lccccccc}\text { HA/FA } & 0.4909 & 0.0006 & -0.1397 & 0.7685 & 0.5780 & 0.5076 & -0.9282 \\ \text { RICS } & 0.7637 & -0.3247 & -0.7760 & 0.6189 & -0.0902 & -0.2296 & -0.8458\end{array}$

0.9863

S B

Bioactivity

0.5181

$-0.3482$

$-0.7358$

0.1950

$-0.4379$

$-0.5426$

$-0.1599$

0.1527

0.5913

t

0.6032
0.5490

$-0.0695$

0.9937
0.2580

$\mathbf{T}$
0.9232

0.6086

$\frac{\mathbf{V}}{-0.8679}$

$0.6086-0.2349$

$-0.4426$

0.4404

(1) $\mathrm{CS}=$ soil organic carbon stock; HA/FA = ratio between humic- and fulvic acid fractions; RICS = redox index of carbon stability; Bioactivity = bioactivity of humic substances; C = soil organic carbon content (Walkley \& Black method); $\mathrm{pH}=1: 2.5$ soil:water ratio; $\mathrm{P}$ and $\mathrm{K}=$ Mehlich-1 extraction; $\mathrm{Ca}^{2+}, \mathrm{Mg}^{2+}$ and $\mathrm{Al}^{3+}=1 \mathrm{~mol} \mathrm{~L} \mathrm{~L}^{-1} \mathrm{KCl}$ extraction; $\mathrm{H}+\mathrm{Al}=0.5 \mathrm{~mol} \mathrm{~L} \mathrm{~L}^{-1}$ calcium acetate, $\mathrm{pH} 7.0 ; \mathrm{SB}=\mathrm{K}^{+}+$ with $60 \mathrm{mg} \mathrm{L}^{-1} \mathrm{P}$ at a $1: 10$ ratio.

Table 5: Matrix of correlations of carbon stocks, their stabilities, and their bioactivities with selected soil quality indicators (correlation was considered narrow when $r>0.7000$ )

\begin{tabular}{lccccccccccccc}
\hline Variables $^{(\mathbf{1})}$ & LOM & FAF & FA & HA & HUM & TC & CS & HS & SHS & HA/FA & COX & RICS & Bioactivity \\
\hline CS & 0.8369 & 0.2470 & 0.4884 & 0.3658 & 0.6858 & 0.9549 & 1.0000 & 0.4094 & 0.3361 & 0.2593 & 0.4082 & 0.7165 & 0.6045 \\
HA/FA & 0.5286 & 0.4261 & 0.9627 & 0.9931 & 0.1278 & 0.5297 & -0.9474 & 0.9854 & 0.9212 & 1.0000 & 0.1231 & 0.3565 & -0.2101 \\
RICS & 0.3582 & -0.3598 & 0.5773 & 0.4488 & 0.9721 & 0.6990 & 0.7165 & 0.4947 & 0.1399 & 0.3565 & 0.3444 & 1.0000 & 0.8385 \\
Bioactivity & 0.0737 & -0.6187 & 0.0437 & -0.1090 & 0.9426 & 0.4281 & 0.6045 & -0.0563 & -0.3880 & -0.2101 & 0.2805 & 0.8385 & 1.0000 \\
\hline
\end{tabular}

(1) $\mathrm{CS}=$ soil organic carbon stock; HA/FA = ratio between humic and fulvic acid fractions; RICS = redox index of carbon stability; Bioactivity = bioactivity of humic substances; LOM = light organic matter; $\mathrm{FAF}=$ free fulvic acid; FA = fulvic acids; HA = humic acids; HUM = humin; TC = total carbon; HS = humic acids + fulvic acids; SHS = stock of humic substances; COX = oxidation capacity of humic acids. 
Table 6. Matrix of correlations of carbon stocks, their stabilities, and their bioactivities with selected physical soil attributes (correlation was considered narrow when $r>0.7000$ )

\begin{tabular}{|c|c|c|c|c|}
\hline Variables $^{(1)}$ & PD & SD & TP & MRP \\
\hline$\overline{\mathrm{CS}}$ & ${ }^{\wedge} 0.3106$ & 0.2688 & ${ }^{\wedge} 0.4003$ & 1.0000 \\
\hline $\mathrm{HA} / \mathrm{FA}$ & “0.3715 & 0.2868 & “”0.8806 & “0.9474 \\
\hline RICS & ${ }^{\wedge} 0.8842$ & 0.8644 & 0.7254 & 0.7165 \\
\hline Bioactivity & ${ }^{\wedge} 0.7046$ & 0.7329 & ^0.2441 & 0.6045 \\
\hline
\end{tabular}

(1) $\mathrm{CS}$ = soil organic carbon stock; HA/FA = ratio between humic and fulvic acid fractions; RICS = redox index of carbon stability; Bioactivity = bioactivity of humic substances; $\mathrm{PD}=$ particle density; $\mathrm{SD}=$ soil density; $\mathrm{TP}=$ total porosity; $\mathrm{MRP}=$ mean resistance to penetration.

correlated with the increases in CS quantity and stability and may also have destabilized organic matter through leaching during the single IFLF cycle. This hypothesis could be supported by the relationship between RICS and free fulvic acid, which has relatively more soluble organic matter than do humic acids and substances. In future studies, attention should be given to the effects of changes in physical soil parameters on RICS and how this information could be used to promote conservationist agricultural management practices.

\section{CONCLUSIONS}

The soil quality indicators studied, redox properties, and bioactivity of humic acids were correlated. The results indicated that the reintroduction of forests alongside conventional farming and livestock management resulted in the reconstruction simultaneously of soil physical, chemical, and biological properties.

The positive correlations between redox properties and bioactivity of humic acids isolated from contrasting management systems allow to infer that redox sites may be associated with the bioprovenance properties in the humic substances, increasing the retention capacity of biopolymers in the organic supramolecular structure.

Two main mechanics could explain this increase of bioactivity concomitantly with redox activity of humic acids: i) directly, by the retention of biopolymers by oxidation/reduction reactions; and ii) indirectly, by the stabilization of the supramolecular arrangements of the humified organic matter.

Results still confirm that integrated farming-livestockforest, this innovative, conservationist land management approach can lead to further developments in agrotechnology and agricultural public policies.

\section{ACKNOWLEDGMENTS}

This work was financed by CNPq, FAPEMIG, and FUNARBE. The authors wish to thank the students, staff, and teachers of the Universidade Federal de Viçosa, and the Central West regional unit of the Empresa de Pesquisa Agropecuária de Minas Gerais, who have continuously supported this project.

\section{REFERENCES}

Alvarez V VH \& Alvarez GAM (2003) Apresentação de equações de regressão e suas interpretações. Boletim Informativo da Sociedade Brasileira de Ciência do Solo, 28:28-32.

Anjos JT, Uberti AAA, Vizzoto VJ, Leite GB \& Kriegrer M (1994) Propriedades físicas do solo sob diferentes sistemas e usos de manejo. Revista Brasileira de Ciência do Solo, 18:139-145.

Araújo R, Goedert WJ \& Lacerda MPC (2007) Qualidade de um solo sob diferentes usos e sob cerrado nativo. Revista Brasileira de Ciência do Solo, 31:1099-1108.

Canellas LP, Mendonca ES, Dobbss LB, Baldotto MA, Velloso ACX \& Amaral Sobrinho NMB (2008) Reações da matéria orgânica. In: Santos GA, Silva LS, Canellas LP \& Camargo FAO (Eds.) Fundamentos da matéria orgânica do solo: ecossistemas tropicais e subtropicais. $2^{\mathrm{a}}$ ed. Porto Alegre, Metrópole. p.4563.

Baldotto MA, Muniz RC, Baldotto LEB \& Dobbss LB (2011) Root growth of Arabidopsis thaliana (L.) Heynh. treated with humic acids isolated from typical soils of Rio de Janeiro state, Brazil. Revista Ceres, 58:504-511.

Baldotto MA, Canela MC, Canellas LP, Dobbss LB \& Velloso ACX (2010) Redox índex of soil carbon stability. Revista Brasileira de Ciência do Solo, 34:1543-1551.

Baldotto MA \& Baldotto LEB (2014) Ácidos húmicos. Revista Ceres, 61:856-881.

Baldotto MA, Vieira EM, Souza DO \& Baldotto LEB (2015) Estoque e frações de carbono orgânico e fertilidade de solo sob floresta, agricultura e pecuária. Revista Ceres, 62:301-309.

Baldotto MA, Souza AC, Viana MCM, Almeida DD \& Baldotto LEB (2017) Bioatividade das substâncias húmicas extraídas de solos manejados com integração, lavoura, pecuária e floresta. Revista Ceres, 64:540-547.

Canellas LP, Façanha AO, Façanha AR \& Olivares FL (2002) Humic acids isolated from earthworm induces root mitotic sites and plasma membrane H+-ATPase. Plant Physiology, 30:19511957.

Canellas LP \& Olivares FL (2014) Physiological responses to humic substances as plant growth promoter. Chemical and Biological Technologies in Agriculture, 1:03-14.

Carvalho JLN, Avanzi JC, Silva MLN, Mello CR \& Cerri CEP (2010) Potencial de sequestro de carbono em diferentes biomas do Brasil - Revisão de Literatura. Revista Brasileira de Ciências do Solo, 34:277-289.

Cruz CD (2006) Análise multivariada e simulação. Viçosa, Editora UFV. $175 \mathrm{p}$.

CBHSF (2016) Comitê hidrográfico da bacia do Rio São Francisco. Disponível em: 〈http://cbhsaofrancisco.org.br/o-cbhsf>. Acessado em: 21 de setembro de 2016. 
Cerri CEP, Coleman K, Jenkinson DS, Bernoux M, Victoria R \& Cerri CC (2003) Modeling soil carbon from forest and pasture ecosystems of Amazon, Brazil. Soil Science Society of America Journal, 67:879-1887.

Cibapar - Consórcio Intermunicipal da Bacia Hidrográfica do Rio Paraopeba (2016) Bacia do Rio Paraopeba. Disponível em: $<$ http://www.aguasdoparaopeba.org.br/index.php $>$. Acessado em: 21 de setembro de 2016

Coelho JS, Araújo SAC, Viana MCM, Villela SDJ, Freire FM \& Braz TGS (2014) Morfofisiologia e valor nutritivo do capimbraquiária em sistema silvipastoril com diferentes arranjos espaciais. Semina: Ciências Agrárias, 35:1487-1500.

Embrapa - Empresa Brasileira de Pesquisa Agropecuária (1997) Manual de métodos de análise de solo. $2^{\mathrm{a}}$ ed. Rio de Janeiro, Centro Nacional de Pesquisa em Solos. 212p.

Embrapa - Empresa Brasileira de Pesquisa Agropecuária (2018) Centro Nacional de Pesquisa em Solos. Sistema Brasileiro de Classificação de olos. $5^{\text {a }}$ ed. Rio de Janeiro, Embrapa CNPS. $815 \mathrm{p}$.

IHSS - International Humic Substances Society (2016) Products. Disponível em: <http://www.ihss.gatech.edu/products.html>. Acessado em: 10 de outubro de 2016.

IPCC - Intergovernmental Panel on Climate Change (2016) Climate Change 2007: Mitigation of Climate Change. Working Group III Report. <http://www.ipcc.ch/ipccreports/ar4wg3.htm>. Acessado em: 10 de outubro de 2016.

Macedo MCM (2009) Integração lavoura e pecuária: o estado da arte e inovações tecnológicas. Revista Brasileira de Zootecnia, $38: 133-146$.
MAPA - Ministério da Agricultura, Pecuária e Abastecimento (2016) Recuperação de Áreas Degradadas. Disponível em: <http:// www.agricultura.gov.br/desenvolvimento-sustentavel/ recuperacao-areas-degradadas $>$. Acessado em: 21 de setembro de 2016.

Nardi S, Pizzeghello D, Muscolo A \& Vianello A (2002) Physiological effects of humic substances on higher plants. Soil Biology and Biochemistry, 34:1527-1536.

Piccolo A (2001) The supramolecular structure of humic substances. Soil Science, 166:810-832.

Ribeiro AC, Guimarães PTG \& Venegas VHA (Eds.) Recomendações para uso de corretivos e fertilizantes em Minas Gerais: $5^{\text {a }}$ Aproximação. Viçosa, Comissão de Fertilidade do Solo do Estado de Minas Gerais. 359P.

Steel RGD \& Torrie JH (1980) Principles and procedures of statistics. $2^{\text {nd }}$ ed. New York, McGraw-Hill. 633p.

Struyk Z \& Sposito G (2001) Redox properties of standard humic acids. Geoderma, 102:329-346.

Sposito G (2008) The chemistry of soils. $2^{\text {nd }}$ ed. New York, Oxford University Press. 330p.

Taiz L \& Zeiger E (2003) Fisiologia vegetal. $3^{\text {a }}$ ed. Porto Alegre, Artmed. 719p.

Viana MCM, Mascarenhas MHT, Queiroz DS, Magalhaes LL, Melido RCN, Ofugi C \& Gomes RJ (2010) Experiências com o Sistema de Integração Lavoura-Pecuária-Floresta em Minas Gerais. Informe Agropecuário, 31:98-111.

Vilela L, Martha Junior GB, Macedo MCM, Marchão RL, Guimaraes Junior R, Pulrolnik K \& Maciel GA (2011) Sistemas de integração lavoura-pecuária na região do Cerrado. Pesquisa Agropecuária Brasileira, 46:1127-1138. 